Analysis

\title{
Reconfiguring an irrigation landscape to improve provision of ecosystem services
}

\author{
Neville D. Crossman ${ }^{\text {a, } *}$, Jeffrey D. Connor ${ }^{\text {a }}$, Brett A. Bryan ${ }^{\text {a }}$, David M. Summers ${ }^{\text {a }}$, John Ginnivan ${ }^{\text {b }}$ \\ a Policy and Economic Research Unit, CSIRO Sustainable Ecosystems, Urrbrae, SA, Australia \\ ${ }^{\mathrm{b}}$ Goulburn Murray Water, Tatura, Victoria, Australia
}

\section{A R T I C L E I N F O}

\section{Article history:}

Received 23 March 2009

Received in revised form 14 September 2009

Accepted 18 November 2009

Available online 16 December 2009

\section{Keywords:}

Landscape planning

Geographic information systems

Cost-benefit analysis

Irrigation

Climate change

Water management

Spatial targeting

Environmental valuation

\begin{abstract}
A B S T R A C T
Over-allocation of fresh water resources to consumptive uses, coupled with recurring drought and the prospect of climate change, is compromising the stocks of natural capital in the world's basins and reducing their ability to provide water-dependent ecosystem services. To combat this, governments worldwide are making significant investment in efforts to improve the sharing of water between consumptive uses and the environment. Many investments are centred on the modernisation of inefficient irrigation delivery systems and the purchase of consumptive water for environmental flows. In this study, we applied spatial targeting within a cost-benefit framework to reconfigure agricultural land use in an irrigation district to achieve a $20 \%$ reduction in agricultural water use to increase environmental flows, and improve the provision of other ecosystem services. We demonstrate a targeted land use reconfiguration policy approach using spatial planning and optimisation models. Our model estimates a potential increase in the net present value of ecosystem services of up to \$A 347 million. The increase in ecosystem services include recovering $62 \mathrm{GL}$ of water for environmental flows, the sequestration of 10.6 million tonnes of $\mathrm{CO} 2 \mathrm{e} / \mathrm{year}$, a $12 \mathrm{EC}(\mu \mathrm{S} / \mathrm{cm})$ reduction in river salinity, and an overall $9 \%$ increase in the value of agriculture. Without a spatially targeted approach to planning, a 20\% reduction in water for irrigation could result in the loss of \$A 68.7 million in economic returns to agriculture which may be only marginally offset by the increased value of ecosystem services resulting from the return of $62 \mathrm{GL}$ of water to the environment.
\end{abstract}

Crown Copyright (c) 2009 Published by Elsevier B.V. All rights reserved.

\section{Introduction}

Irrigation of agricultural crops in low-rainfall regions of the world is an important element of world food production. Yet water security and water-dependent ecosystems in many irrigated areas are threatened by the increase in demand for water to meet food requirements of growing populations, coupled with intermittent droughts and the prospect of continued reduced runoff and water supply as a consequence of humaninduced climate change. The focus of this paper is the evaluation of targeted policy to mitigate ongoing water shortages and erosion of natural capital in irrigation regions. This is an issue in Australia (Quiggin, 2001; Qureshi et al., 2007), California (Doremus and Tarlock, 2003; Burke et al., 2004), the Mediterranean region (Isendahl and Schmidt, 2006; Hein, 2007) and parts of Asia (Datta et al., 2004; Shah, 2005). All of these regions are grappling with the impacts of unsustainable use and over-allocation of water (Postel, 2003; Hillel and Vlek, 2005; Wichelns and Oster, 2006). In Australia, significant public finances are being invested in irrigation water management (Wong, 2008a), which includes the reorganisation and reconfiguration of irrigation landscapes. This study presents a reconfiguration planning approach that helps resolve the over-allocation of water without compromising the

\footnotetext{
* Corresponding author.

E-mail address: neville.crossman@csiro.au (N.D. Crossman).
}

economic value of irrigated agricultural production, while at the same time returning water to the environment. The approach aims to increase the value of ecosystem services provided by landscapes that have irrigation as a major land and water use.

The concept of ecosystem services centres on the idea that natural ecosystems provide a wide range of benefits to humans, and the benefits have economic value. The services that ecosystems provide include provisioning, regulating, and cultural services that directly affect people, and the supporting services needed to maintain functionality of the system. The valuing of ecosystem services dates back to the 1970 s (Westman, 1977), rising to prominence with Costanza et al. (1997) and Daily (1997). There exist a number of practical applications that evaluate investments accounting for a wide range of ecosystem service values within water and non-water environmental domains. Examples include Wilson and Carpenter (1999), Heal (2000), Loomis et al. (2000), Daily and Ellison (2002), National Research Council of the National Academies (2005), Bateman et al. (2006), and Yang et al. (2008). The economic value of watersheds (Pattanayak, 2004; Zheng et al., 2008) and wetlands (Loomis et al., 2000; Zedler, 2003; Tong et al., 2007; Yang et al., 2008) has been found to be substantial because of the wide range of ecosystem services that they provide.

In this paper we combine ecosystem service valuation and spatial targeting methodologies. Spatial targeting and landscape planning to underpin agricultural policy intervention have been recently shown to provide significant environmental gains for potentially small 
economic costs (Yang et al., 2003; Ferraro, 2004; Lee and Thompson, 2005; Bailey et al., 2006; Messer, 2006; Saroinsong et al., 2007; van der Horst, 2007; Wünscher et al., 2008; Crossman and Bryan, 2009). Messer (2006) show that conservation benefits of an existing land acquisition could be obtained for up to \$US 3.5 million less using spatial optimisation and targeting. Saroinsong et al. (2007) demonstrated that applying smart landscape planning to a fast eroding catchment in Indonesia could reduce soil loss by $75 \%$ for only a $3.1 \%$ reduction in total agricultural profitability. Crossman and Bryan (2009) show that locating 53,000 ha of ecological restoration (or $1 \%$ of the landscape area) in a targeted way within the most cost-effective locations, could improve the annual income of degraded dryland farms and provide carbon and biodiversity benefits. In contrast Crossman and Bryan (2009) find that less targeted restoration would lead to much lower ecosystem benefits. These studies demonstrate the efficacy of spatially targeted investment and its advantages as an analytical framework. We contend that extension of spatial targeting and ecosystem service valuation methods into irrigated agricultural landscapes could provide a framework for identifying ways to reduce over-allocation of water resources whilst increasing rather than decreasing ecosystem service returns to land and water.

We used a case study approach to develop and apply spatially targeted planning and ecosystem service valuation tools for reconfiguring an irrigation landscape in southern Australia to operate with less water. Our objective was to plan for the reconfiguration of land use and to jointly increase the net ecosystem service values of water and land use, including agricultural production, amenity, salinity and carbon sequestration. We constructed hierarchical, rule-based and optimisation planning models to identify zones of potential land use change based on a set of spatially explicit constraints for enhancing the provision of ecosystem services. We then quantified the economic value of ecosystem services, including agricultural production. We compared the value under our planned model to a random unplanned scenario achieving the same water savings. Our results demonstrate the advantage of strategic spatial targeting of land use change in irrigation landscapes under less water availability and of accounting for a wide range of ecosystem service values. Our results also identify potential ways to improve the returns to public investment in water resource management.

\section{Study Area and Policy Setting}

The geographic focus of the project is the Torrumbarry Irrigation Area in northern Victoria, Australia (Fig. 1). The dominant land use is irrigation and the major commodities produced are dairy and beef cattle, grains and high-value horticulture (Bryan et al., 2009a). Irrigation water is intercepted and diverted from the major waterways in the study area, including the River Murray, the border between the states of New South Wales and Victoria. Water supply and management of irrigation infrastructure is the responsibility of the local water management authority, Goulburn-Murray Water. The long history of intensive land use and the associated widespread clearance of native vegetation have resulted in a landscape with few small pockets of remnant natural ecosystems. Two RAMSAR wetlands of international significance adjoin the study area, and the region contains several other important water bodies and watercourses (Fig. 1).

The study area is a part of the Murray Darling Basin, a region under significant stress from over-allocation of water for irrigation and which has been in drought since the early 2000s (CSIRO, 2008). The reduced runoff in recent low-rainfall years has resulted in a system now characterised by substantially reduced natural flow and consistently low allocations of water for irrigation (Young and McColl, 2009). Under climate change, protracted droughts are predicted to become more common (Hennessey et al., 2008; Garnaut 2008) and surface water availability in the study area is estimated to fall by $14 \%$ (CSIRO, 2008). Compounding the problem of reduced flows, river salinity is expected to exceed the World Health Organisation desirable drinking water standard more than half of the time by 2020 if recent trends continue (Murray-Darling Basin Commission, 2005). Garnaut (2008) estimates that the impacts of climate change may result in a $50 \%$ reduction in annual irrigated agricultural output in the Basin by 2050. Irrigated agriculture in the Basin is estimated to be worth $\$ A 5$ billion annually (Quiggin, 2001; Bryan et al., 2009b). Policies are now in place to reduce salinity, increase water available for environmental flows, and adapt to climate change. The most notable of these is the Australian Government's \$A 12.9 billion Water for the Future program which aims to 'secure the long term water supply of all Australians' and address 'the problem of over-allocation and improve river health' in the Murray Darling Basin (Wong, 2008a). The Water for the Future program includes \$A 5.8 billion for replacement of inefficient irrigation infrastructure and \$A 3.1 billion for purchasing water entitlements from irrigators (Wong, 2008a). Investments are required to demonstrate a positive benefit-cost ratio and account for the full cost of water use (Australian Government, 2008a), that is, provide greatest net benefit accounting for the full suite of values of ecosystem services.

A landscape-scale spatial planning and prioritisation problem arises when deciding where to invest in irrigation infrastructure and water purchases that provide the greatest ecosystem service benefits for the least cost. There is opportunity to increase total benefits by targeting water license acquisition in areas where co-benefits in the form of salinity impact reductions are high (McColl and Young, 2005). Water purchases could also be targeted in locations where low value irrigation water can be returned to the system and existing land management replaced with native trees that provide carbon sequestration, biodiversity and recreational amenity benefits (Bryan and Crossman, 2008; Crossman and Bryan, 2009). Further, consolidating remaining irrigation in a smaller area on soils suitable for irrigation could enhance agricultural productivity and reduce the marginal costs of water supply.

Water trade has been occurring in the region independent of any targeted planning and prioritisation. Land use change has occurred on properties where water entitlements have been traded out of the study area, creating a landscape mosaic of irrigated agriculture interspersed with a random mix of fallow and new non-irrigated land uses (Fig. 2). Per property, the cost of delivering water under this spatial configuration is inefficient. Spatial planning can identify strategies to achieve targeted agricultural water use reduction characterised by more costeffective water delivery and enhanced ecosystem service provision.

\section{Methods}

\subsection{Defining the Elements of Reconfiguration}

A preliminary task was to consult with local irrigators, water delivery and natural resource management professionals to conceptualise the reconfiguration of water, land, and water delivery infrastructure to increase the value of ecosystem services. Discussions during two local workshops, each with approximately 12 individuals representing local farmers, the irrigation water supply corporation, and State and local natural resource management agencies, and a series of smaller meetings, concluded that irrigated land use in the study area could be reconfigured into three planning zones that jointly increase the value of ecosystem services and reduce water delivery costs. Different water investment strategies would be applied in each zone:

- Green Zone: Invest in updating irrigation infrastructure. Returns to water use in irrigation could be increased and the cost of delivering water decreased by consolidating remaining irrigation and delivery infrastructure onto a smaller area at a higher water utilisation rate. - Red Zone: Purchase water and convert to low value dryland agriculture. River salinity could be reduced if irrigation were discontinued in areas where drainage results in high salt loads to the River Murray. 


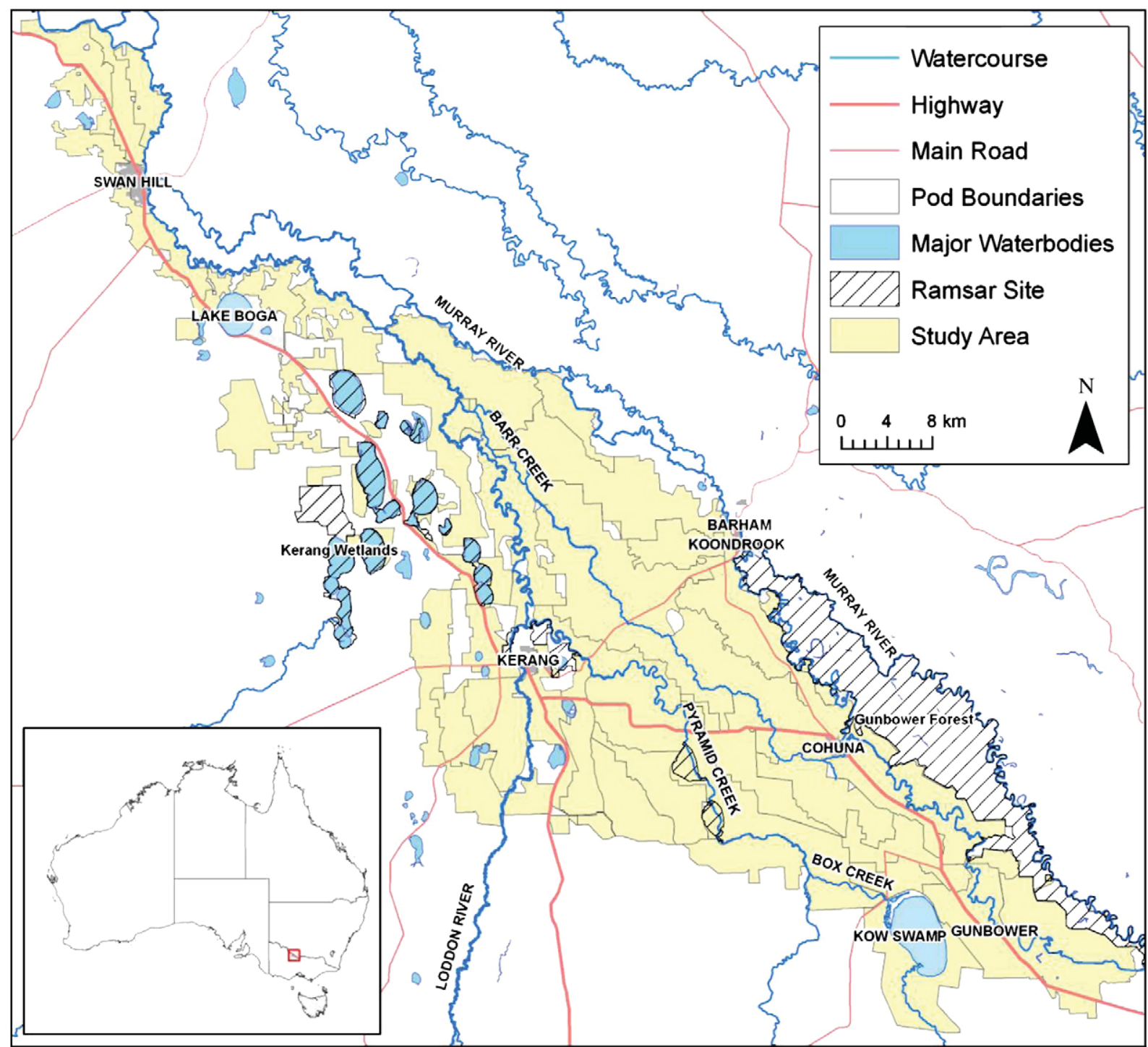

Fig. 1. The Torrumbarry Irrigation Area in northern Victoria, Australia.

- Amber Zone: Purchase water and convert to carbon sinks. Carbon sequestration and amenity values could be enhanced through replacement of crops with plantings of native tree species in areas where there exist potential biodiversity, amenity and carbon sequestration benefits.

Two scales of units of analysis were used in this study: i) fine-scale individual properties from the cadastral boundary dataset, and; ii) coarse-scale Goulburn-Murray Water delivery infrastructure units called 'pods'. Pods are defined by spatially contiguous groupings of 1050 properties all delivered by a single second order delivery canal (Fig. 1). The pod is a unit in which the water delivery service could be discontinued without affecting the whole system. As a corollary the irrigation pod is the focus of reconfiguration policy and investment decisions. Spatial variables were modelled at the property scale where possible and generalised to the pod scale for final analysis and reporting.

\subsection{Quantifying Ecosystem Service Values}

Ecosystem service values were calculated in present value (PV) or net present value (NPV) terms over a time horizon of $30(t=30)$ years at a discount rate $r$ of $7 \%$.

\subsubsection{River Salinity}

Water purification and the resulting fresh water is a service provided by a functioning riparian ecosystem. Irrigation in the study area contributes to downstream river channel salinity by mobilising salt in the soil and transporting it into the river system via drainage and discharge (Connor, 2008). Increased salt concentrations compromise the fresh water resource and impose a cost on downstream users of water through damage to infrastructure and reduced irrigated crop yields. The total river salinity ecosystem service value for cessation of irrigation and conversion to dryland agriculture or native tree plantings was computed as the sum of the changes in drainage following conversion, the estimated salinity impact per unit of drainage by location, and the estimated dollar benefit per unit of salinity avoided.

Values for salinity load per unit drainage were taken from spatially varying estimates of electro-conductivity unit $(\mathrm{EC},(\mu \mathrm{S} / \mathrm{cm}))$ savings per gigalitre (GL), or 1 billion litres, of discontinued irrigation across the Barr Creek Catchment (SKM, 2008). The estimated cost per unit salinity used in the study is $\$ A 150,000$ per EC per annum (National Land and Water Resources Audit, 2002), which is equal to \$A 2.01 million in PV terms.

While the \$A 150,000 per EC estimate accounts for crop and municipal industrial infrastructure salinity damages, it omits any value for damage to high-value ecological assets and therefore is thought to be conservative (Connor, 2008). As an upper bound estimate, the cost of 


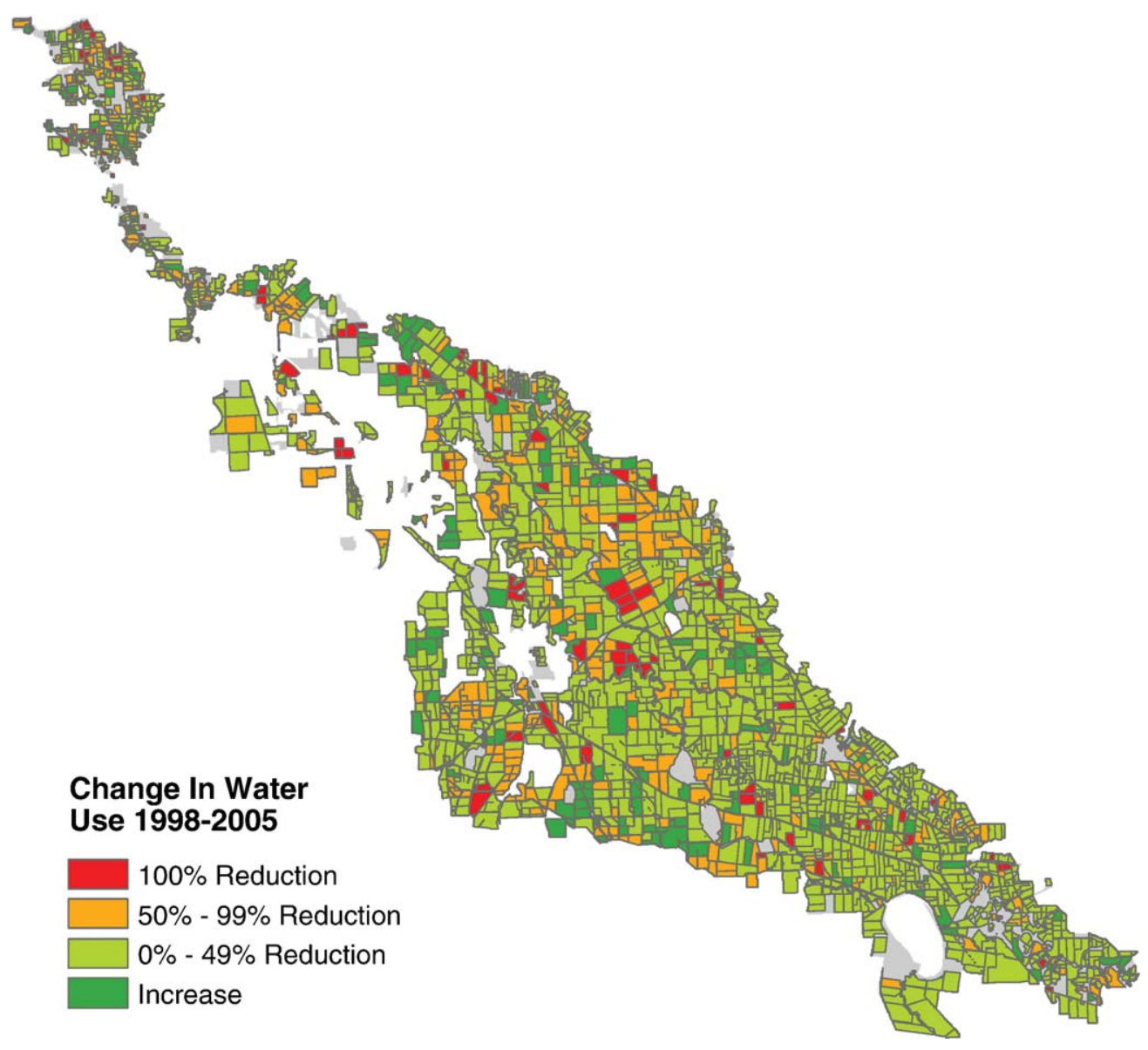

Fig. 2. Property scale change in water use in the Torrumbarry Irrigation Area, 1998 to 2005 (unpublished data).

removing salt from the river using salt interception schemes is approaching \$A 3-4 million per EC (Connor, 2008). Therefore the ecosystem service value of less salt in the river is assumed to be in the range of \$A 2.01 million-\$A 4 million per EC in PV terms.

\subsubsection{Carbon Sequestration}

Climate regulation and the resulting stable atmosphere is another service provided by correctly functioning ecosystems. Biosequestration of atmospheric carbon dioxide through reforestation reduces the concentration of carbon. The total carbon sequestration value for conversion from irrigation to native tree plantings was computed as the sum of the area converted to tree plantings multiplied by the carbon dioxide equivalents ( $\mathrm{CO} 2 \mathrm{e}$ ) per ha and the dollar benefit per tonne of $\mathrm{CO} 2 \mathrm{e}$ reduction.

The spatially explicit version of 3-PG tree productivity simulations (Sands and Landsberg, 2002) was used to estimate the carbon captured in the tree biomass. The well established 3-PG process model simulates tree growth based on a series of spatial soil and climate input layers and stand management variables. The parameter set for Eucalyptus kochii, a low-rainfall mallee species, was used to estimate total carbon. The model was run for a 30-year period at a planting density of 1200 stems per hectare. The soil texture (sand, sandy loam, loam and clay) and available soil water holding capacity $(\mathrm{mm})$ inputs required by 3-PG were created from detailed regional soil maps and associated survey manuals available from the Department of Primary Industries Victoria (2007). Available soil water holding capacity was calculated as a function of the rooting depth of each soil texture class and an available soil water multiplier that varies according to soil texture. Mean monthly climate surfaces (maximum temperature, minimum temperature, precipitation, and daily solar radiation) were derived for the study area using the ESOCLIM module of ANUCLIM 5.0 (Houlder et al., 1999) based on a digital elevation model (DEM). Total dry biomass produced per hectare $b_{t}$ for each year $t$ from 3-PG was converted to carbon sequestration potential $Q_{t}$ in carbon dioxide equivalent terms (CO2e):

$$
Q_{t}=3.667\left(\frac{b_{t}-b_{t-1}}{2}\right)
$$

The market price of $\$ A$ 20/t CO2e under a carbon cap-and-trade system is used to calculate the ecosystem service value of carbon sequestration. It is expected that landowners who reforest their land will be able to sell the annual carbon sequestered in the Australian Carbon Pollution Reduction Scheme due to commence in 2011 (Australian Government, 2008b). The \$A 20/t CO2e market price was chosen because it is a price repeatedly modelled for analyses on the impact of the Australian Carbon Pollution Reduction Scheme (e.g. Garnaut, 2008; Lawson et al., 2008). Net Present Value (NPV) per hectare from carbon trading was calculated as:

$N P V=\sum_{t=0}^{T} \frac{P \times Q_{t}-\left(E C_{t}+M C\right)}{(1+r)^{t}}$

where $P$ is the price of carbon $(P=\$ 20 / \mathrm{t} \mathrm{CO2e}), Q_{t}$ is the quantity of CO2e sequestered in year $t, \mathrm{EC}_{t}$ is the establishment cost $\left(\mathrm{EC}_{t}=\right.$ $\$ 1000 /$ ha at $t=0,0$ otherwise), MC is the annual maintenance cost $(\mathrm{MC}=\$ 10 / \mathrm{ha})$, and $r$ is the discount rate $(r=7 \%)$.

\subsubsection{Productive Agriculture}

An ecosystem service of substantial value is the production of agricultural commodities for human consumption. The value of this service can be quantified spatially by modelling agricultural profitability according to land and water use. Methods used to calculate profit at full 
equity PFE for each agricultural land use category are based on Bryan et al. (2009b) and involved calculating the gross revenue less the variable and fixed costs to determine net returns to the farmer. The general form of the profit function is:

PFE $=($ Price $*$ Yield $)-($ Variable Costs + Fixed Costs $)$

Production statistics and prices for each commodity typically grown under each land use type in the study area were derived from the Australian Bureau of Statistics (2007) Agricultural Commodities data. Four gross margin handbooks (Wimalasuriya, 1998; Montecillo and Reeves, 2006; Montecillo et al., 2006; English, 2007) were used in cases where Agricultural Commodities data was not used because of potential error. Fixed and variable costs, including water, were derived from previous studies (Bryan et al., 2009b) and gross margin handbooks (Wimalasuriya, 1998; Montecillo and Reeves, 2006; Montecillo et al., 2006; English, 2007). Profit at full equity was spatially allocated using the agricultural land use dataset derived from cadastral and land use data. The annual profit values were converted to NPV.

\subsubsection{Environmental Flows}

Fresh water flow acts as a provisioning and supporting ecosystem service by maintaining the biological diversity and integrity of the fresh water systems. The value of environmental flows to industries can be measured using market values. For example, the economic value of amenities on the Murray River to industry has been estimated at \$A 2.7 billion/year (Howard, 2008). However, it is more difficult to quantify ecosystem service values of improved river health from environmental flows not extracted for irrigation or other consumptive uses. Robust estimates of these values require an understanding of ecological responses to increased flows coupled with estimated non-market values of improvements in environmental quality, such as increased ecological function and improved human use value. We have relied on a recent study which estimated the NPV of increased environmental flows for improving the health of the predominant ecological community (river red gum, Eucalyptus camaldulensis) along the River Murray given various volumetric and temporal scenarios (Bennett et al., 2008). The study valued increased flows at $\$ A 500$ per megalitre (ML) to $\$ A 2200$ per ML over a 20 -year period with a $6 \%$ discount rate.

\subsubsection{Recreation and Amenity}

Cultural and aesthetic value is a core ecosystem service provided by natural landscapes and it is thought to have a significant value in the study area (Howard, 2008). However, measuring them is a challenge because many of these values are not traded in markets. We used results from a stated preference study of Australian land and water resources (van Bueren and Bennett, 2004) which applied a choice modelling questionnaire to 3200 randomly selected Australian households. Choice sets centred on species protection, landscape aesthetics, riparian health and social impact. The aim was to quantify household willingness to pay for improvements in the environment. Relevant to the present study is the finding relating to landscape aesthetics that households were willing to pay to have farmlands repaired and bush area protected. The average willingness to pay was \$A 0.07 (range 0.02-0.14) per 10,000 ha of landscape restored per household per year over 20 years (van Bueren and Bennett, 2004).
This figure was converted to aggregated per hectare PV for the population as a whole using the following function:

$P V=0.45^{*} H H^{*}\left(\sum_{t=0}^{T} \frac{A_{\mathrm{WTP}}}{(1+r)^{t}}\right)$

10,000

where $A_{\text {WTP }}$ is household's willingness to pay for a restored landscape, $\mathrm{HH}$ is the total number of Australian households $(\mathrm{HH}=7.596$ million (Australian Bureau of Statistics, 2006)), and 0.45 is an aggregation factor that moderates the total number of households to account for non-respondents in the original survey (van Bueren and Bennett, 2000).

\subsection{Water Delivery Cost Savings}

Reconfiguration of an irrigation district that results in the retiring of irrigation will result in delivery cost savings relating to assetreplacement and maintenance present values, the annual operational cost and the loss-entitlement costs. Annual delivery costs used here apply at the pod scale and were calculated by Morse-McNabb (2006). Values range from \$A 5.86/ML to \$A 56/ML. The annual delivery costs were then converted to PV terms.

\subsection{Reconfiguration Planning}

\subsubsection{Decision Tree Model}

Transparency and ease of communication were of primary importance in constructing a spatial planning model given the critical and controversial nature of the land and water reconfiguration problem. Hence, a decision tree planning model was developed to identify priority locations for targeting land use change, investment in water purchases and irrigation infrastructure modernisation. The decision tree model is a hierarchical, rule-based spatial planning model that prioritises ecological restoration as a first priority in areas where farming could lead to degradation of high-value ecological assets. The remaining areas with high irrigation productivity potential were chosen for irrigation given a future reduction in water availability. Remaining land was allocated to dryland farming. The model incorporates information on a number of decision criteria within a Geographic Information System (GIS). Five decision criteria were identified as being important in planning for irrigation reconfiguration (Table 1).

High-value environmental assets, environmental amenity and residential areas (Table 1 ) were identified in the study area and buffered by $500 \mathrm{~m}$. High-value environmental assets were defined according to the local catchment management strategies (North Central Catchment Management Authority, 2003, 2005) and include the major watercourses, lakes and RAMSAR wetlands in the study area. The $500 \mathrm{~m}$ buffer distance was chosen based on consultation with key local water management personnel. Residential and environmental amenity areas include the major towns, patches of remnant native vegetation 10 ha or greater in size, and major lakes and watercourses. The floodplain is defined as those areas that are regularly flooded and would require substantial management inputs if used for intensive irrigation (Spatial Sciences Group, 2006). The proportion of each property within the

Table 1

Spatial layers of ecosystem service decision criteria used in the decision tree analysis and the critical cut-offs used. Note EC $=$ electrical conductivity unit $(\mu \mathrm{S} / \mathrm{cm})$.

\begin{tabular}{ll}
\hline Criteria & Critical cut-off point \\
\hline Land suitability for irrigation & $\geq 9$ suitability score \\
Salinity impact & $\geq 0.2$ EC reduction at Morgan per $1000 \mathrm{ML}$ irrigation ceased \\
Connection to high-value environmental assets & $\geq 75 \%$ of the property within $500 \mathrm{~m}$ of high-value environmental asset \\
Connection to floodplain ecosystems & $\geq 75 \%$ of the property in the floodplain \\
Connection to residential and environmental amenity areas & $\geq 75 \%$ of the property within $500 \mathrm{~m}$ of residential and environmental amenity areas \\
\hline
\end{tabular}


floodplain, buffered environmental assets, and buffered residential and environmental amenity areas was calculated in the GIS. Planting of trees in locations of high environmental value and on the floodplain provides ecological benefits by buffering and linking remnant and fragmented habitats and providing critical habitat for floodplain dependent species. Tree planting in amenity areas is assumed to increase the value of the heavily cleared landscapes in the study area.

Salinity impact to the River Murray from irrigation activities in the Barr Creek Catchment (Table 1), as quantified using the metric 'ECs at Morgan', was calculated by independent modelling (SKM, 2008). SKM (2008) estimated the EC savings per $1000 \mathrm{ML}$ irrigation ceased across the Barr Creek Catchment using historic salt load information from two benchmark periods, 1975-2000 and 1975-2007. The 1975-2000 benchmark period data and associated EC reduction per $1000 \mathrm{ML}$ irrigation ceased was used in this study to quantify the salinity impacts of reduced irrigation because it represents a more typical series of seasons. The 1975-2007 period includes the recent drought which results in lower, and hence underestimated, salt loads.

A layer describing the land suitability for irrigation was acquired from The Department of Primary Industries Victoria. Land suitability includes assessment of soil suitability for irrigation, sub-soil salinity, water table depth and subsurface drainage, and soil waterlogging risk. Full details are available in the Kerang Irrigation Region Atlas (Spatial Sciences Group, 2006). A mean suitability score was calculated for each property.

Critical cut-offs were defined for each criteria that influence the nature of the investment for landscape reconfiguration (Table 1). These were implemented as queries using Structured Query Language (SQL) in a GIS, producing five binary layers with values for each property for each of the five criteria. The decision tree model was applied to identify zones of land use change based on these binary decision criteria layers and implemented using spatial overlay operations in a GIS (Fig. 3). However, decisions about irrigation water delivery and management of infrastructure are made at the pod scale by the water utility, GoulburnMurray Water. Therefore, an analytical filter was passed over the properties allocated by the decision tree to remove within-pod heterogeneity of properties belonging to different investment categories. A majority rule was used whereby a pod was allocated to the land use change category that corresponded with the majority of properties within the pod boundary.

\subsubsection{Green Zone Optimisation Model}

After excluding some pods from irrigation on ecological, amenity, and salinity criteria using the decision tree planning model, a second model was used to consolidate irrigation into fewer pods within the remaining area suitable for irrigation. Consolidation of irrigation was motivated by the need to reverse the existing inefficient delivery and use of water following the trade of water out of the study area (Fig. 2). In the study area there are differences in both water application rates per hectare and potential economic returns to water between pods. These were estimated and used in an optimisation routine to locate irrigation preferentially in pods in the order of highest potential economic return to water from irrigation. Irrigation water was allocated to pods until their available area for irrigation was exhausted. Pods were selected until the aggregate water availability $W$ was utilised. The objective of the optimisation was to maximise overall profit from irrigation in the study area:

Maximise $\sum_{i=1} r_{i} a_{i} h_{i}$

subject to:

$h_{i} \leq v_{i}$,

$\sum_{i=1} a_{i} h_{i} \leq W$

where $h_{i}$, the decision variable, is the area (ha) of irrigation located in pod $i$ and $r_{i}$, is the average return (\$/ML) of irrigation water applied, and $a_{i}$ is the average irrigation water application rate (ML/ha) for pod $i$. The optimisation was subject to two constraints. The first constraint requires that the area of newly consolidated irrigation within in any pod $h_{i}$, not exceed the total area available for irrigation in the pod $v_{i}$. The second constraint requires that total irrigation water use is less than or equal to the amount available $W$, which in this study is $80 \%$ of current (2005) water use. Pods where no irrigation was allocated were converted to the lowest value dryland agriculture (i.e. reclassified into red zones) with a NPV of \$A 1696/ha (Table 2).

\subsection{Analysis Scenarios}

The costs and benefits of the targeted land use planning scenario were calculated to evaluate potential returns to agriculture and ecosystem services. These were compared to a current (2005) baseline value of agricultural production in the study area. In addition, the targeted reconfiguration scenario was compared to an unplanned or non-targeted scenario. The unplanned scenario quantifies net agricultural and ecosystem service values given the same amount of

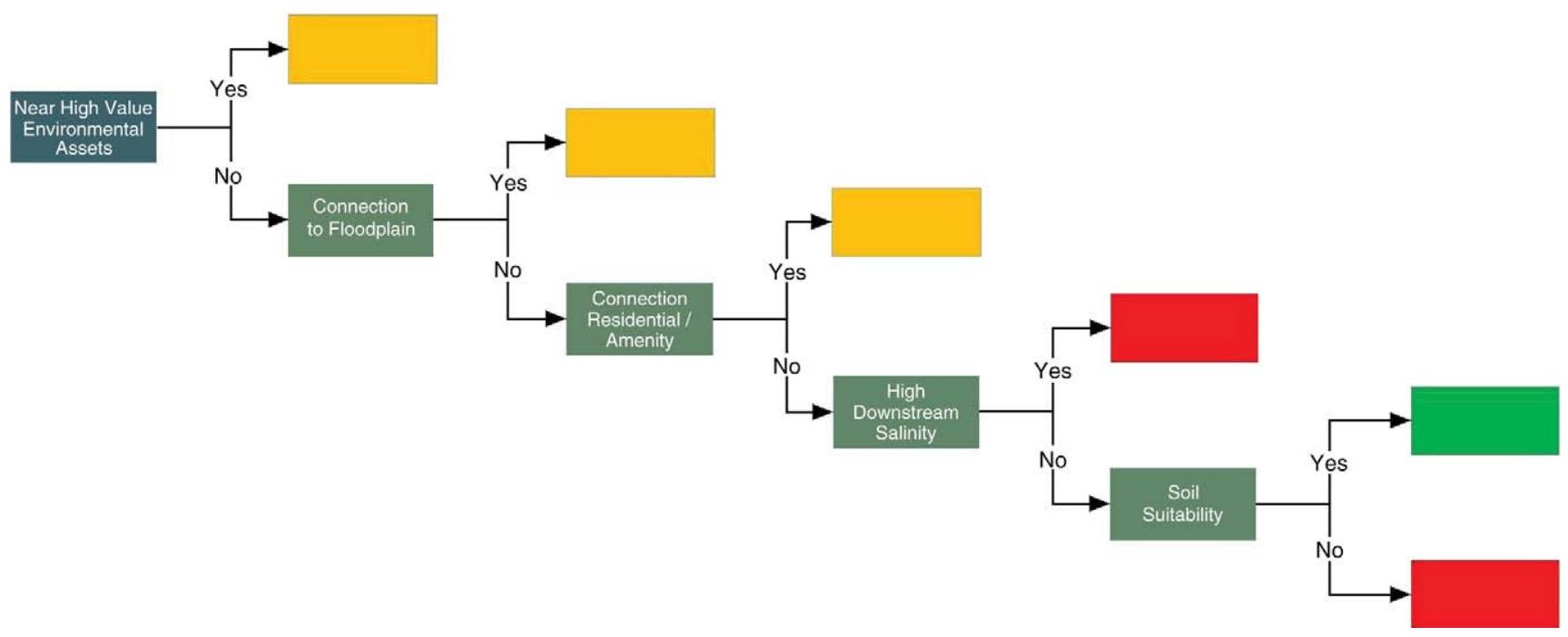

Fig. 3. The decision tree used to spatially target properties for investment. The investment priority categories are identified by the red, amber and green coloured boxes. 
Table 2

Summary of ecosystem service values used in this study.

\begin{tabular}{|c|c|c|c|}
\hline Variable & Description & Units & Values $(\$ A)$ \\
\hline River salinity & Avoided costs of removing salt from the River Murray through cessation of irrigation & PV \$/ML & $0-4823$ \\
\hline Stable climate & Value of carbon sequestered by reforestation of irrigation areas, assuming $\$ A$ 20/t CO2e & NPV \$/ha & $4377-5404$ \\
\hline Productive agriculture & Value of additional agriculture (dryland and irrigated) possible under reconfigured landscape & NPV \$/ha & $1696-98,490$ \\
\hline Environmental flows & Value of water returned to the environment for increased flows & NPV \$/ML & $500-2200$ \\
\hline Recreation and amenity & Value of reforested and restored landscapes for visual amenity and recreational enjoyment & PV \$/ha & $96-642$ \\
\hline
\end{tabular}

water savings as in the targeted scenario. This scenario quantifies the net values of less water without any attempt to target how and where land, water and water delivery infrastructure are used. Irrigated properties were randomly selected to cease irrigation until the total volume of water of selected properties reached a threshold equivalent to the volume of water returned to environment under the planned targeted scenario, which in this case is $20 \%$ of the water used under the 2005 baseline. While the spatial pattern of reductions in water use under the non-targeted scenario were randomly identified, they are arguably similar to the observed trends between 1998 and 2005 (Fig. 2) and thus represent what might be expected with a continuation of past trends.

\subsection{Sensitivity Analysis}

The sensitivity of each decision criteria (Fig. 3) to the critical cut-offs (Table 1) was explored by iteratively adjusting the cut-off value of each criteria while keeping the other criteria constant. The effect of adjusting cut-offs was reported through the impact on the total value of agricultural production and water returned for environmental flows.

\section{Results}

Table 2 summarises the ecosystem service values quantified in this study. Ecosystem service value of salinity reduction is up to $\$ A 4823$ / $\mathrm{ML}$ in PV terms. The ecosystem service value of carbon sequestration, assuming a market price of \$A 20/t CO2e, ranges from \$A 4377/ha to \$A 5404/ha in NPV terms. The ecosystem service value of agricultural production estimates range from \$A 1696/ha for dryland pasture on the most limited soils in the region to $\$ A 98,490 /$ ha for irrigated horticulture on the best soils in the region. The value of restored landscapes is in the range $\$ A 96 /$ ha to $\$ A 642 /$ ha in PV terms. The delivery cost is in the range $\$ A 79 / \mathrm{ML}$ to $\$ A$ 751/ML in PV terms.

Input variables summarised and mapped at the property scale are presented in Fig. 4. The ecosystem service value of converting a property to non-irrigated land uses (dryland farming and reforestation) displays considerable heterogeneity across the landscape (Fig. 4a to e). The larger properties in the central part of the study area, around the Barr Creek and Loddon River, are of greater value to ecosystem service provision. In some cases, individual properties could provide in the order of $\$ A 20$ 30 million in ecosystem service value through cessation of irrigation. The soils less suitable for irrigation are located predominantly in the central parts of the study area, around the Barr Creek and Loddon River (Fig. 4g). The central locations are also where there are properties in close proximity to high-value environmental assets, residential and amenity living areas and the floodplain (Fig. $4 \mathrm{~h}$ to j).

Application of the decision tree planning model identifies properties and pods for allocation to the green (irrigation), red (dryland agriculture) and amber (ecological restoration) zones (Fig. 5a and b). The application of the optimisation model for targeted location of irrigation reduces the number of pods under irrigation (categorised as belonging to the green zone) as shown in Fig. 5c. This results in an increase in the value of irrigated agriculture as a result of consolidating irrigation in more productive areas with greater economic returns, and improving delivery infrastructure utilisation (Table 3 ). The red and amber pods are targeted for water purchases and alternative dryland agriculture and ecological restoration land uses, respectively. Ecological restoration in the amber pods improves the provision of ecosystem services to a greater extent than in the red or green pods.

Table 3 summarises the results of the scenario analysis. The low to high range of ecosystem service values for river salinity, environmental flows and recreation and amenity ecosystem services are estimated based on the ranges per unit listed in Table 1. In the current scenario estimated total net economic returns to agriculture in the study area was \$A 777.7 million in NPV terms. Annually, agriculture in the study area is worth $\$ A 58$ million assuming a 2004/05 water use of 305 GL. No ecosystem service values are reported for the current scenario in Table 3 because it is a baseline and changes from this baseline are reported in the other analysis scenarios.

In the non-targeted and targeted scenarios a total of $62 \mathrm{GL}$ of water (20\% less than in 2004/05) was assumed to be no longer available for irrigation. In the non-targeted scenario $20 \%$ less water was estimated to result in a \$A 68.7 million or a $9 \%$ decline in the value of agriculture to $\$ A 709$ million from the current baseline of $\$ A 777.7$ million over a 30 -year period. No water delivery cost savings are estimated in this scenario because it was assumed that all infrastructure must be maintained to service the spatially disparate spread of customers that could be expected with a random pattern of reduced water use by irrigators. The random pattern is arguably similar to the 1998-2005 trend in land use change (Fig. 2). The non-targeted scenario would lead to a rising per unit delivery cost for the expected smaller number of irrigators. A decline in salinity impact on downstream water users was estimated in this scenario of $5 \mathrm{EC}$ at Morgan which could be worth up to $\$ A 23$ million over the next 30 years.

The results of the targeted scenario suggest that the value of targeted reconfiguration of land, water and infrastructure use can enhance net economic returns to the region. In the targeted scenario, despite $20 \%$ less irrigation water, a \$A 72.5 million or $9 \%$ increase in the value of agriculture over a 30 -year period could be expected through smart spatial targeting and planning. In addition there are potential water delivery cost savings of approximately \$A 26.3 million that are attainable with a spatially targeted strategy.

The expected increase in ecosystem service values is up to $\$ A$ 90.8 million and \$A 347 million under the non-targeted unplanned and targeted planned scenarios, respectively. The environmental flow value from the $62 \mathrm{GL}$ returned to the environment is the same for both scenarios, but values are higher for the other ecosystem services under the targeted scenario. In biophysical terms, estimated benefit of the targeted scenario is a $12 \mathrm{EC}$ reduction of salinity at Morgan. The potential value of the additional salinity reduction in the targeted scenarios is $\$ A$ 30 million greater than the value of salinity reduction estimated to result in the non-targeted scenario. Revegetation and ecological restoration has the estimated potential to provide climate change benefits in the order of 10.6 million tonnes of CO2e sequestered over a 30 -year period with an estimated economic value of up to \$A 75 million over 30 years. The restored treed landscapes along lengths of the Loddon River, River Murray and Kerang Lakes in this scenario also offer potential for significant recreational and amenity benefits with an estimated value of up to \$A 10.1 million.

Fig. 6 demonstrates the sensitivity of the decision criteria to adjustments of the critical cut-offs. A tightening of the cut-offs by adjusting thresholds to the left of their current values (Fig. 6) will 

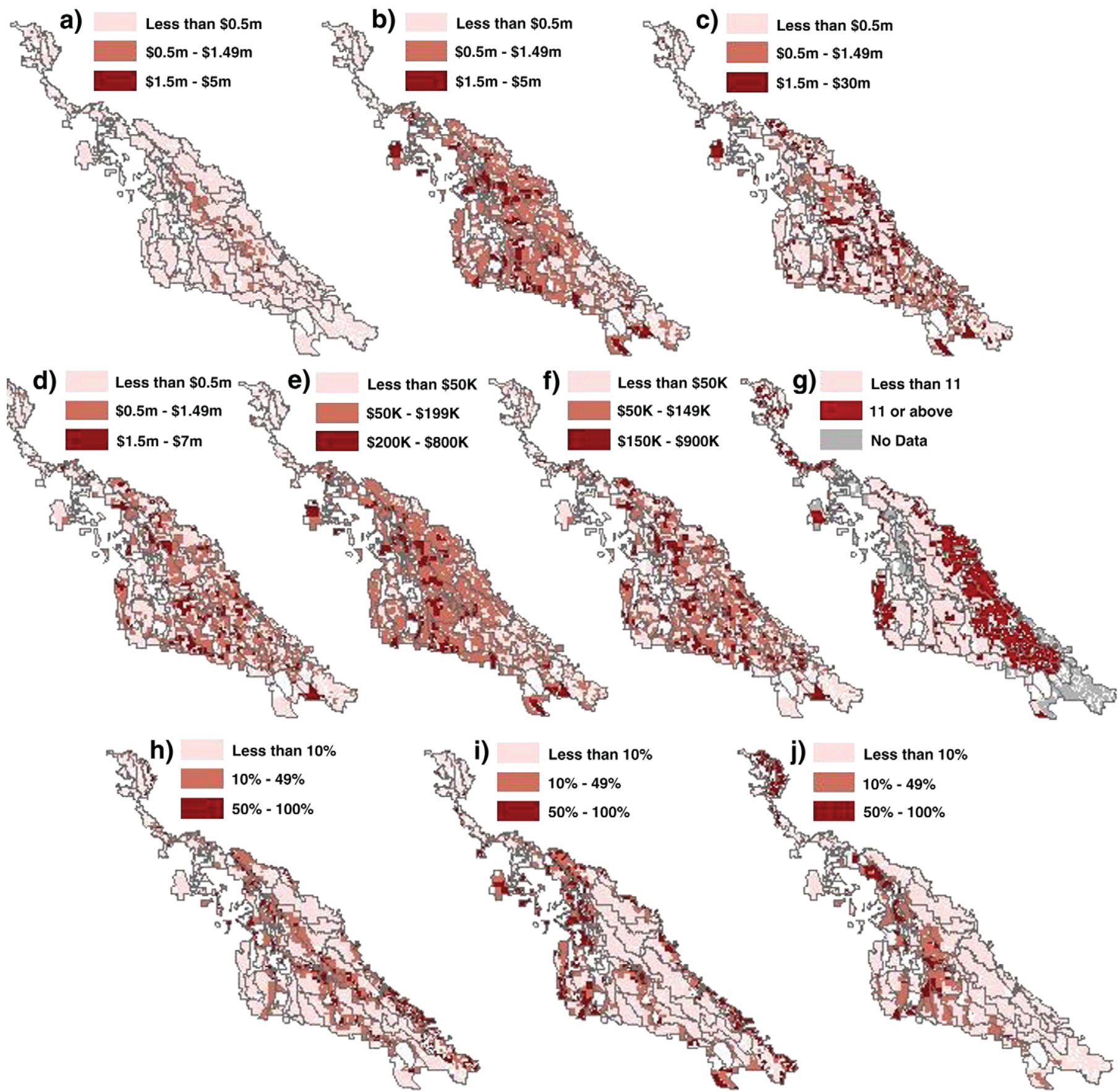

j) Less than $10 \%$

Fig. 4. Input variables summarised at the property scale: a) upper bound NPV of avoided costs of removing salt from the River Murray through cessation of irrigation; b) NPV of carbon sequestered by reforestation of irrigation areas; c) NPV of agriculture; d) upper bound of total value of water returned to the environment for increased flows; e) upper bound of NPV of reforested and restored landscapes for visual amenity and enjoyment; f) NPV of infrastructure maintenance, operation, replacement and loss-entitlement costs; $g$ ) average land suitability for irrigation score; $\mathrm{h}$ ) proportion of the property within $500 \mathrm{~m}$ of key environmental assets; i) proportion of the property within $500 \mathrm{~m}$ of residential and amenity living areas, and; $\mathrm{j}$ ) proportion of the property within the floodplain.

increase the volume of water available for the environment but the trade-off will be lower agricultural production values because there will be less irrigated agriculture. The EC reduction decision criteria is the most sensitive to a tightening of cut-offs. For example, shifting the EC reduction from 0.2 ECs to $0.15 \mathrm{EC}$ will result in $130 \mathrm{GL}$ of water potentially available for restoring natural flows, i.e. $43 \%$ less water for irrigation. The NPV of agricultural production would be approximately \$A 740 million, a \$A 37 million reduction in the current baseline over a 30 -year period. The other decision criteria are not as sensitive but a shift in cut-off will nonetheless result in a trade-off between environmental water and agricultural production value. The critical cut-offs selected for our model therefore provides a balance between ecosystem service benefits, in this case environmental water, and the value of agricultural production (Fig. 6).

\section{Discussion}

Through smart targeting of investment in irrigation infrastructure and water entitlement purchases, $20 \%$ of the region's water could be returned to the River Murray with positive impacts on ecosystem service and agricultural production. Significant water delivery costs savings could also be realised. Twelve ECs can be avoided at Morgan, 
a)

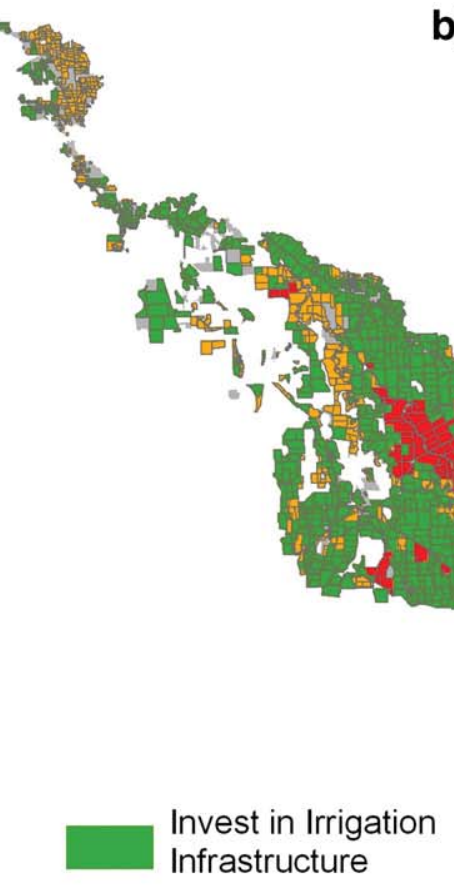

b)

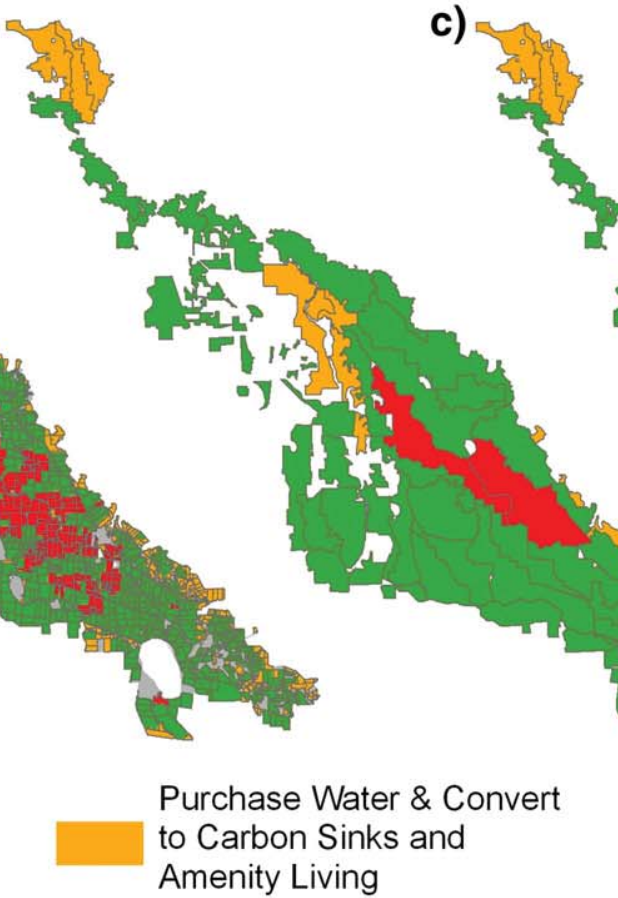

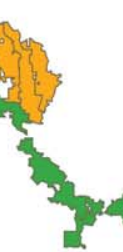

Fig. 5. a) Properties that belong to the green, amber and red groups for targeting investment in irrigation infrastructure modernisation and water purchases; b) the up-scaled pod level category membership, and; c) the category membership after optimisation.

10.6 million tonnes of CO2e equivalents sequestered annually by over 20,000 ha of reforestation, and 62 GL of water could be returned to the system for restoring natural flows, while at the same time increasing the value of agricultural production by $9 \%$. Several points warrant discussion, namely the methods used to arrive at the ecosystem service values and those used for spatial targeting and benefit/cost analysis and the policy mechanisms for implementing such an extensive landscape-scale reconfiguration.

\subsection{Valuation Methods and Limitations}

A diverse mix of techniques and literature were used to value the ecosystem services considered in this study. Valuing the ecosystem service of improved recreation and amenity landscapes relied on value estimates derived using non-market valuation techniques, with the associated values 'transferred' to the ecosystems of the study area. The benefit transfer approach has been criticised for its lack of robustness and consistency between environmental goods and market characteristics, as well as the context in which changes are made (Brouwer, 2000; van Bueren and Bennett, 2004; Spash and Vatn, 2006). However, the values can arguably be transferred to landscapes in the study area given that the values used here were derived for similar environmental assets within relatively close proximity. Others have used revealed preference techniques such as hedonic price models (e.g. Luttik, 2000; Cho et al., 2006; White and Leefers, 2007), but these suffer from their own set of limitations centred on their location specificity and inability to capture the full set of ecosystem value that accrue far from the property market analysed.

Table 3

Summary of values and ecosystem service benefits. All dollar figures are PV or NPV (\$A million).

\begin{tabular}{|c|c|c|c|c|}
\hline & & Current & Non-targeted & targeted \\
\hline \multirow[t]{3}{*}{ NPV of agriculture } & Irrigated & $\$ 743.2$ & $\$ 642.0$ & $\$ 781.7$ \\
\hline & Dryland & $\$ 34.7$ & $\$ 67.0$ & $\$ 68.5$ \\
\hline & Total & $\$ 777.7$ & $\$ 709.0$ & $\$ 850.2$ \\
\hline \multirow[t]{7}{*}{ Ecosystem service values } & Productive & n.a. & $-\$ 68.7$ & $\$ 72.5$ \\
\hline & Agriculture $^{\mathrm{a}}$ & & & \\
\hline & River salinity & n.a. & $\$ 11.6-\$ 23.0$ & $\$ 26.6-\$ 52.9$ \\
\hline & Stable climate & n.a. & $\$ 0.0$ & $\$ 75.0$ \\
\hline & Environmental flows & n.a. & $\$ 31.0-\$ 136.5$ & $\$ 31.0-\$ 136.5$ \\
\hline & Recreation and amenity & n.a. & $\$ 0.0$ & $\$ 1.5-\$ 10.1$ \\
\hline & Total & n.a. & $-\$ 26.1-\$ 90.8$ & $\$ 206.6-\$ 347.0$ \\
\hline Water & & n.a. & $\$ 0.0$ & $\$ 26.3$ \\
\hline \multicolumn{5}{|l|}{ Delivery } \\
\hline \multicolumn{5}{|l|}{ Cost } \\
\hline \multicolumn{5}{|l|}{ Savings } \\
\hline \multirow[t]{4}{*}{ Total benefit } & & & $-\$ 26.1-\$ 90.8$ & $\$ 232.9-\$ 373.3$ \\
\hline & Environmental water (GL) & n.a. & 62 & 62 \\
\hline & ECs avoided & n.a. & 5 & 12 \\
\hline & Carbon sequestered (million tonnes $\mathrm{CO} 2 \mathrm{e})^{\mathrm{b}}$ & n.a. & 0 & 10.6 \\
\hline
\end{tabular}

\footnotetext{
a The ecosystem service value of productive agriculture is the increase in value of agriculture from the baseline current scenario.
}

b Total is for the 30-year period of the 3-PG simulation model. 

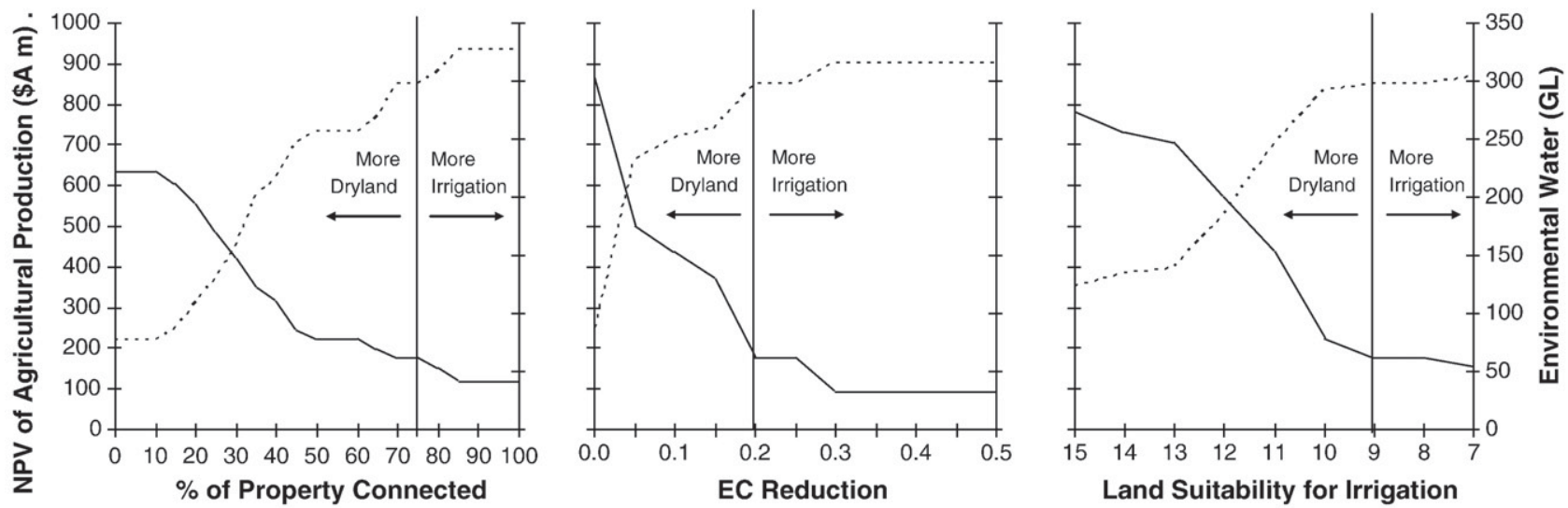

Fig. 6. Sensitivity of NPV of agricultural production (dashed line, left hand side) and water available for the environment (solid line, right hand side) to changes in the critical cut-offs of each decision criteria. Cut-offs used in the model are presented for each decision criteria.

The production method can be used to estimate the value of increased economic productivity attributable to river flows, such as the value of commercial fishing. However, this method generally yields a lower bound value for ecosystem services because consumer surplus is not considered, as found in a number of wetland valuation studies (Boyer and Polasky, 2004). Damage cost and cost avoidance techniques used in this study for valuing river salinity are well established and justifiable (Connor et al., 2008). Similarly, the use of market activity for estimating the value of a stable climate is equally justifiable.

The value estimates of increased environmental flows are the least robust of the ecosystem service value estimates and should be used with the greatest caution. Despite the critical nature of increasing environmental flows and the difficulty of doing so in recent years due to an extended dry period and low inflows, the monetary value of water for the environment is still relatively poorly quantified. The reason is the complexity of ecosystem water requirements for maintaining system health and diversity.

\subsection{Spatial Targeting and Benefit/Cost Analysis}

Spatial targeting approaches for improved environmental outcomes have been classified into three types, those that target: i) benefits; ii) costs, or; iii) benefit-cost ratios (Babcock et al., 1997). The present study applies benefit targeting where benefits are described as salinity impact reductions, the value of agricultural production and ecosystem service values including carbon sequestration and amenity recreational benefits. The study is not a formal cost-benefit analysis in that the costs of attaining the estimated benefits are not fully accounted; omissions include the cost of buying water for environmental flow and costs associated with reconfiguration of land uses and infrastructure. However, the study does provide the basis for benefit cost analysis by identifying the threshold level of investment that would be justified on the basis of benefits that it produces (Table 3). With further work to understand the full range of costs involved, the framework developed for the present study could be extended to evaluate the benefit-cost ratio of potential public investments in a full cost benefit analysis.

\subsection{Policy Mechanisms for Implementation}

From the results it is evident that the benefits from investment are possible from strategically targeted policy that encourages significant land use change across the irrigation landscape. How will this arise? A range of policy mechanisms already exist at all levels of Australian government that could help to facilitate irrigation landscape reconfiguration for increased ecosystem service values. Commonwealth and State Governments are individually and jointly making very substantial investments into reducing river salinity, modernising irrigation infrastructure and purchasing water for environmental flows. For example, the Water for the Future program includes $\$ \mathrm{~A}$ 5.8 billion for replacement of inefficient irrigation infrastructure (Wong, 2008a). The Murray Darling Commission Basin Salinity Management Strategy has resulted in an investment in salinity mitigation of over \$A 100 million dollars (Connor, 2008).

Mature water markets have already moved water allocations away from low productivity uses towards higher value uses elsewhere. The Murray Darling Basin is now, arguably, the most active water market in the world (Peterson et al., 2005) with up to $20 \%$ of water allocations traded from some supply areas (URS, 2005). In addition, there is likely to be an increasing demand for water to enhance environmental flows and state and federal Governments are entering the market to meet these requirements. A further $\$ A 3.1$ billion of the Water for the Future program will be spent purchasing water entitlements from irrigators (Wong, 2008a). At the time of writing, a \$A 50 million pilot has purchased $35 \mathrm{GL}$ of water for the environment (Wong, 2008b). The price paid for water under the $\$ A 50$ million pilot is $\$ A 1.4$ million per GL. At this price it would cost the government $\$ A 87$ million to purchase the $62 \mathrm{GL}$ of water from the amber and red pods in our study area. The return of $62 \mathrm{GL}$ of water would provide $\$ \mathrm{~A} 57.6$ million to $\$ \mathrm{~A}$ 189.4 million in environmental flow and salinity reduction ecosystem service benefits (Table 3 ).

However, efforts at targeting policy and investments for providing multiple ecosystem service benefits are relatively immature. Proposed investments under the Water for the Future program are required to meet a set of due diligence criteria to ensure investments are costeffective while simultaneously improving river health, minimising social impact and providing regional economic security and development opportunities. These criteria imply that investments will focus on providing multiple benefits. However, a recent independent review of the \$A 50 million pilot to purchase $35 \mathrm{GL}$ of water for the environment (Breckwoldt, 2008) demonstrates that price per ML was the overriding concern for selecting water to purchase from irrigators.

Future water purchases could target water purchases where they provide water for the environment and wider ecosystem services such as salinity reduction and carbon sequestration, and delivery cost savings. At present, government water planning and investment for irrigation infrastructure modernisation, environmental flows and salinity reduction, as well as for carbon sequestration arguably lack coordination. Additionally, there are impediments to efficient functioning and coordination of the key private markets involved. Land markets in particular work slowly to reconfigure land uses due to factors such as demographics and capital constraints. There may be considerable benefit in proactive land use planning that actively 
encourages higher value and regional employment generating uses of land resources. Additionally, land banking or brokerage arrangements and financial planning assistance for landholders considering changes in land use may be ways to encourage higher value uses.

\section{Conclusion}

The problem of water scarcity and the unsustainable use and overallocation of water is not unique to Australia (Postel, 2003; Hillel and Vlek, 2005; Wichelns and Oster, 2006). Water shortages and the subsequent impacts on agriculture, society and natural ecosystems are felt in California (Doremus and Tarlock, 2003; Burke et al., 2004), the Mediterranean region (Isendahl and Schmidt, 2006; Hein, 2007) and parts of Asia (Datta et al., 2004; Shah, 2005), to name a few. Our results are specific to the Australian context, especially the ecosystem service values used to quantify the benefits of spatial targeting of investment in water and irrigation infrastructure. However, there is arguably a case for significant public investment in irrigation landscape reconfiguration that provides multiple ecosystem service benefits in any location affected by water scarcity. The form of investment, whether it is smart targeting of water purchases or new irrigation technologies that increase water use efficiencies, or both, will be specific to a region and country. The monetary values used to value ecosystem services will also be location and context specific.

Measuring the size of potential benefits from a targeted approach to land, water and water infrastructure reconfiguration and identifying priority locations based on potential benefit to a case study region has been the focus of our study. Applying our model to another irrigation-dependent region will require research into local ecosystem services and values. There will also need to be relevant policy instruments and institutions for targeting water investments that provide multiple benefits. The next step is to design policy that realises the potential improvements in multiple objective outcomes identified in this study.

\section{Acknowledgements}

This study was supported by the Better Basin Futures Theme within the CSIRO Water for a Healthy Country Flagship. Funding was partly sourced from the Commonwealth Department of Agriculture, Fisheries and Forestry under the Market Based Instruments Pilot Program. Many staff within the North Central Catchment Management Authority, Department of Primary Industries Victoria and Goulburn-Murray Water are thanked for their many contributions ranging from data supply to intellectual and professional input. Significant thanks are given to Jim McColl, John Ward, Sorada Tapsuwan, Parvin Mahmoudi and two anonymous reviewers for valuable comments on an earlier version of this paper.

\section{References}

Australian Bureau of Statistics, 2006. Australian Census of Population and Housing 2006. Australia Bureau of Statistics, Canberra.

Australian Bureau of Statistics, 2007. Agricultural Commodities: Small Area Data, Australia, 2006-07. Australia Bureau of Statistics, Canberra.

Australian Government, 2008a. Agreement on Murray_Darling Basin Reform, 3 July 2008. At URL http://coag.gov.au/coag_meeting_outcomes/2008-07-03/docs/ Murray_Darling_IGA.pdf, accessed on 27/11/2008.

Australian Government, 2008b. Carbon Pollution Reduction Scheme: Australia's Low Pollution Future. Australian Government, December 2008, Canberra. At URL http:// www.climatechange.gov.au/whitepaper/report/index.html, accessed on 20/02/2009.

Babcock, B.A., Lakshminarayan, P.G., Wu, J.J., Zilberman, D., 1997. Targeting tools for the purchase of environmental amenities. Land Economics 73, 325-339.

Bailey, N., Lee, J.T., Thompson, S., 2006. Maximising the natural capital benefits of habitat creation: spatially targeting native woodland using GIS. Landscape and Urban Planning 75, 227-243.

Bateman, I.J., Brouwer, R., Davies, H., Day, B.H., Deflandre, A., Di Falco, S., Georgiou, S., Hadley, D., Hutchins, M., Jones, A.P. Kay, D. Leeks, G., Lewis, M., Lovett, A A. Neal, C. Posen, P., Rigby, D., Turner, R.K., 2006. Analysing the agricultural costs and non-market benefits of implementing the water framework directive. Journal of Agricultural Economics 57, 221-237.

Bennett, J., Dumbsday, R., Gillespie, R., 2008. Analysing options for the Red Gum Forests along the Murray River. Proceedings of the 52nd Australian Agricultural Resource Economics Conference, 5-8 February 2008, Canberra.

Boyer, T., Polasky, S., 2004. Valuing urban wetlands: a review of non-market valuation studies. Wetlands 24, 744-755.

Breckwoldt, R., 2008. Review of the 2007-08 Water Entitlement Purchases: Final Report. Hyder Consulting, Melbourne.

Brouwer, R., 2000. Environmental value transfer: state of the art and future prospects. Ecological Economics 32, 137-152.

Bryan, B.A., Crossman, N.D., 2008. Systematic landscape planning for multiple objective natural resource management. Journal of Environmental Management 88, 1175-1189.

Bryan, B.A., Barry, S., Marvanek, S., 2009a. Quantifying and mapping commodity-level agricultural land use change in the Murray-Darling Basin, Australia 1996/97-2000/ 01. Journal of Land Use Science 4, 131-155.

Bryan, B.A., Hajkowicz, S., Marvanek, S., Young, M.D., 2009b. Mapping economic returns to agriculture for informing environmental policy in the Murray-Darling Basin, Australia. Environmental Modelling and Assessment 14, 375-390.

Burke, S.M., Adams, R.M., Wallender, W.W., 2004. Water banks and environmental water demands: case of the Klamath project. Water Resources Research 40, W09S02.

Cho, S.H., Bowker, J.M., Park, W.M., 2006. Measuring the contribution of water and green space amenities to housing values: an application and comparison of spatially weighted hedonic models. Journal of Agricultural and Resource Economics 31 , 485-507.

Connor, J., 2008. The economics of time delayed salinity impact management in the River Murray. Water Resources Research 44, W03401.

Connor, J., Doble, R., Walker, G., Stenson, M., Elmahdi, A., Ferris, M.M., Jolly, I.D., Kirby, M., Kaczan, D., Morrison, J.B., King, D., Pickett, T., Overton, I., Pettit, C., 2008. Lower Murray Landscape Futures: Analysis of Regional Plans and Landscape Futures for the River Corridor. At URL http://www.landscapefutures.com.au/publications.html, accessed on $21 / 11 / 2008$.

Costanza, R., d'Arges, R., de Groot, R.S., Farber, S., Grasso, M., Hannon, B., Limburg, K., Naeem, S., O'Neill, R.V., Paruelo, J., Raskin, R.G., Sutton, P., van den Belt, M., 1997. The value of the world's ecosystem services and natural capital. Nature 387, 253-260.

Crossman, N.D., Bryan, B.A., 2009. Identifying cost-effective hotspots for restoring natural capital and enhancing landscape multi-functionality. Ecological Economics $68,654-668$.

CSIRO, 2008. Water availability in the Murray. A Report to the Australian Government from the CSIRO Murray-Darling Basin Sustainable Yields Project. CSIRO, Australia.

Daily, G.C. (Ed.), 1997. Nature's Services: Societal Dependence on Natural Ecosystems. Island Press, Washington DC.

Daily, G.C., Ellison, K., 2002. The New Economy of Nature: The Quest to Make Conservation Profitable. Island Press, Washington DC.

Datta, K.K., Tewari, L., Toshi, P.K., 2004. Impact of subsurface drainage on improvement of crop production and farm income in northwest India. Irrigation and Drainage Systems 18, 43-56.

Department of Primary Industries Victoria, 2007. Detailed Soils Surveys. . At URL http:// www.dpi.vic.gov.au/dpi/vro/nthcenregn.nsf/pages/nthcen_soil_dssurveys, accessed on $23 / 11 / 2007$.

Doremus, H., Tarlock, A.D., 2003. Fish, farms and the clash of cultures in the Klamath basin. Ecology Law Quarterly 30, 279-350.

English, W., 2007. Dairy Industry Farm Monitor Project Summary of Results 2006-2007. Department of Primary Industries, Victoria.

Ferraro, P.J., 2004. Targeting conservation investments in heterogeneous landscapes a distance function approach and application to watershed management. American Journal of Agricultural Economics 86, 905-918.

Garnaut, R., 2008. The Garnaut Climate Change Review: Final Report. Cambridge University Press, Melbourne.

Heal, G., 2000. Nature and the Marketplace: Capturing the Value of Ecosystem Services. Island Press, Washington DC.

Hein, L., 2007. Assessing the costs of land degradation: a case study for the Puentes Catchment, southeast Spain. Land Degradation and Development 18, 631-642.

Hennessey, K., Fawcett, R., Kirono, D., Mpelasoka, F., Jones, D., Bathols, J., Whetton, P., Stafford Smith, M., Howden, M., Mitchell, C., Dlummer, N., 2008. An Assessment of the Impact of Climate Change on the Nature and Frequency of Exceptional Climatic Events. CSIRO and Bureau of Meteorology, Canberra.

Hillel, D., Vlek, P., 2005. The sustainability of irrigation. Advances in Agronomy 87, 55-84.

Houlder, D., Hutchinson, M., Nix, H., McMahon, J., 1999. ANUCLIM Users' Guide. Australian National University, Canberra, Australia.

Howard, J.L., 2008. The future of the Murray River: amenity re-considered? Geographical Research 46, 291-302.

Isendahl, N., Schmidt, G., 2006. Drought in the Mediterranean: WWF Policy Proposals. At URL http://assets.panda.org/downloads/wwf_drought_med_report_2006.pdf, accessed on $31 / 10 / 2008$

Lawson, K., Burns, K., Low, K., Heyhoe, E., Ahammad, H., 2008. Analysing the economic potential of forestry for carbon sequestration under alternative carbon price paths. Australian Bureau of Agricultural and Resource Economics, Canberra, November 2008. At URL http://www.treasury.gov.au/lowpollutionfuture/consultants_report/ downloads/Economic_Potential_of_Forestry.pdf, accessed on 10/02/2009.

Lee, J.T., Thompson, S., 2005. Targeting sites for habitat creation: an investigation into alternative scenarios. Landscape and Urban Planning 71, 17-28.

Loomis, J., Kent, P., Strange, L., Fausch, K., Covich, A., 2000. Measuring the total economic value of restoring ecosystem services in an impaired river basin: results from a contingent valuation survey. Ecological Economics 33, 103-117. 
Luttik, J., 2000. The value of trees, water and open space as reflected by house prices in The Netherlands. Landscape and Urban Planning 48, 161-167.

McColl, J.C., Young, M.D., 2005. Managing change: Australian structural adjustmen lessons for water. CSIRO Land and Water Technical Report 16/05, September 2005

Messer, K.D., 2006. The conservation benefits of cost-effective land acquisition: a case study in Maryland. Journal of Environmental Management 79, 305-315.

Montecillo, O.P., Reeves, C., 2006. Loddon Murray Region Horticulture Gross Margins 2005-2006. Department of Primary Industries, Victoria.

Montecillo, O.P., Jones, D., Grey, D., 2006. Northern Victoria Irrigated Cropping Gross Margins 2005-2006. Department of Primary Industries, Victoria.

Morse-McNabb, E., 2006. Strategic View of Service Needs: Torrumbarry Irrigation Area Atlas. Primary Industries Research Victoria. 1876356847.

Murray Darling Basin Commission, 2005. Living Murray Business Plan. Murray Darling Basin Commission, Canberra. At URL http://thelivingmurray.mdbc.gov.au/_data/ page/1480/2005 TLM_Business_Plan.pdf, accessed on 21/10/2008.

National Land and Water Resources Audit, 2002. Australians and Natural Resource Management 2002. National Land and Water Resources Audit, Canberra.

National Research Council of the National Academies, 2005. Valuing Ecosystem Services: Toward Better Environmental Decision-Making. National Academy of Sciences, Washington DC.

North Central Catchment Management Authority, 2003. North Central Regional Catchment Strategy 2003-2007. North Central Catchment Management Authority, Victoria.

North Central Catchment Management Authority, 2005. North Central River Health Strategy. North Central Catchment Management Authority, Victoria.

Pattanayak, S.K., 2004. Valuing watershed services: concepts and empirics from Southeast Asia. Agriculture, Ecosystems, and Environment 104, 171-184.

Peterson, D., Dwyer, G., Appels, D.C., Fry, J., 2005. Water trade in the southern MurrayDarling Basin. The Economic Record 81, S115-S127.

Postel, S.L., 2003. Securing water for people, crops, and ecosystems: new mindset and new priorities. Natural Resources Forum 27, 89-98.

Quiggin, J., 2001. Environmental economics and the Murray-Darling river system. Australian Journal of Agricultural and Resource Economics 45, 67-94.

Qureshi, E., Connor, J., Kirby, M., Mainudin, M., 2007. Economic assessment of environmental flows in the Murray Basin. Australian Journal of Agricultural and Resource Economics $51,283-305$

Sands, P.J., Landsberg, J.J., 2002. Parameterisation of 3-PG for plantation grown Eucalyptus globulus. Forest Ecology and Management 163, 273-292.

Saroinsong, F., Harashina, K., Arifin, H., Gandasasmita, K., Sakamoto, K., 2007. Practical application of a land resources information system for agricultural landscape planning. Landscape and Urban Planning 79, 38-52.

Shah, T., 2005. Groundwater and human development: challenges and opportunities in livelihoods and environment. Water Science and Technology 51,27-37.

SKM, 2008. Market based instruments for the Torrumbarry System: salt export mechanisms from the Barr Creek catchment. Final Report.

Spash, C., Vatn, A., 2006. Transferring environmental value estimates: issues and alternatives. Ecological Economics 60, 379-388.

Spatial Sciences Group, 2006. Kerang irrigation region atlas. Primary Industries Research Victoria. 1876356480
Tong, C., Feagin, R.A., Lu, J., Zhang, X., Zhu, X., Wang, W., He, W., 2007. Ecosystem service values and restoration in the urban Sanyang Wetland of Wenzhou, China. Ecological Engineering 29, 249-258.

URS, 2005. Salinity Impact of Water Trade, Review of Water Trade in the Riverine Plains. Prepared for Murray-Darling Basin Commission, Canberra.

van Bueren, M., Bennett, J., 2000. Estimating community values for land and water degradation impacts. Final Report, Project 6.1.4. National Land and Water Resources Audit, Canberra.

van Bueren, M., Bennett, J., 2004. Towards the development of a transferable set of value estimates for environmental attributes. The Australian Journal of Agricultural and Resource Economics 48, 1-32.

Van der Horst, D., 2007. Assessing the efficiency gains of improved spatial targeting of policy interventions; the example of an agri-environmental scheme. Journal of Environmental Management 85, 1076-1087.

Westman, W.E., 1977. How much are nature's services worth? Science 197, 960-964.

White, E.M., Leefers, L.A., 2007. Influence of natural amenities on residential property values in a rural setting. Society and Natural Resources 20, 659-667.

Wichelns, D., Oster, J.D., 2006. Sustainable irrigation is necessary and achievable, but direct costs and environmental impacts can be substantial. Agricultural Water Management 86, 114-127.

Wilson, M.A., Carpenter, S.R., 1999. Economic valuation of freshwater ecosystem services in the United States: 1971-1997. Ecological Applications 9, 772-783.

Wimalasuriya, R., 1998. North-Central Gross Margins 1998-1999. Department of Natural Resources and Environment.

Wong, P., 2008a. Rudd Government to Invest \$12.9 Billion in Water. . At URL http://www. environment.gov.au/minister/wong/2008/pubs/mr20080429.pdf, accessed on 21/10/ 2008 .

Wong, P., 2008b. Government Water Purchase Secures Rights to 35 billion litres for the Murray Darling. . At URL http://www.environment.gov.au/minister/wong/2008/ pubs/mr20080523.pdf, accessed on 31/10/2008.

Wünscher, T., Engel, S., Wunder, S., 2008. Spatial targeting of payments for environmental services: a tool for boosting conservation benefits. Ecological Economics 65, 822-833.

Yang, W., Khanna, M., Farnsworth, R., Onal, H., 2003. Integrating economic environmental and GIS modelling to target cost effective land retirement in multiple watersheds. Ecological Economics 46, 249-267.

Yang, W., Chang, J., Xu, B., Peng, C., Ge, Y., 2008. Ecosystem service value assessment for constructed wetlands: a case study in Hangzhou, China. Ecological Economics 68 116-125.

Young, M.D., McColl, J.C., 2009. Double trouble: the importance of accounting for and defining water entitlements consistent with hydrological realities. The Australian Journal of Agricultural and Resource Economics 53, 19-35.

Zedler, J.B., 2003. Wetlands at your service: reducing impacts of agriculture at the watershed scale. Frontiers in Ecology and the Environment 1, 65-72.

Zheng, B.F., Duan, J., Jia, J.S., Liu, F., Yan, Y., 2008. Assessment of ecosystem services of Lugu Lake watershed. International Journal of Sustainable Development and World Ecology $15,62-70$ 